\title{
Effect of Environmental Factors and Pesticides on Mycoparasitism of Sclerotinia minor by Coniothyrium minitans
}

\author{
D. E. Partridge, Former Graduate Research Assistant, T. B. Sutton, Professor, Department of Plant Pathology, and \\ D. L. Jordan, Associate Professor, Department of Crop Science, North Carolina State University, Raleigh 27695
}

\begin{abstract}
Partridge, D. E., Sutton, T. B., and Jordan, D. L. 2006. Effect of environmental factors and pesticides on mycoparasitism of Sclerotinia minor by Coniothyrium minitans. Plant Dis. 90:14071412 .

The effects of soil temperature and moisture, and nine pesticides commonly used in peanut production, on the mycoparasitic activity of Coniothyrium minitans on sclerotia of Sclerotinia minor were evaluated. In vitro mycelial growth and conidia germination of $C$. minitans were sensitive to azoxystrobin, chlorothalonil, fluazinam, pyraclostrobin, tebuconazole, and diclosulam. $C$. minitans survived and infected sclerotia of $S$. minor in the presence of azoxystrobin, chlorothalonil, diclosulam, fluazinam, flumioxazin, $S$-metolachlor, pendimethalin, pyraclostrobin, and tebuconazole. Mycoparasitic activity was reduced by all pesticides except $S$-metolachlor compared with the nontreated control. Optimum conditions for infection of sclerotia were temperatures from 14 to $22^{\circ} \mathrm{C}$ and soil moisture from -0.33 to $-1 \mathrm{kPa} \times 10^{2}$. Mycoparasitic activity of $C$. minitans remained high (98\% sclerotia infected) at temperatures ranging from 14 to $22^{\circ} \mathrm{C}$, but decreased at temperatures above $28^{\circ} \mathrm{C}$. Viability of sclerotia was inversely related to the proportion infected by $C$. minitans $(r=-0.9963, P=0.001)$. Mycoparasitic activity also declined when soil moisture was greater than $-1 \mathrm{kPa} \times 10^{2}$ or less than $-0.10 \mathrm{kPa} \times 10^{2}$. These results indicate that $C$. minitans should not be applied when temperatures exceed $28^{\circ} \mathrm{C}$, during extremes in soil moisture, or when there is a high risk of contact with pesticides before it becomes established in the soil.
\end{abstract}

Coniothyrium minitans Campbell is a fungal mycoparasite of sclerotia formed by Sclerotinia spp. and has been shown to be an effective biological control agent in several crops $(6,11,17,18,26,28)$. Sclerotinia blight of peanut (Arachis hypogaea L.), caused by the soilborne fungus Sclerotinia minor (Jaggar) Kohn (14), is an important disease in the peanut-growing regions in Virginia and North Carolina and also is found in Texas, Oklahoma, and New Mexico $(5,25)$. Recent field studies have shown that $C$. minitans can colonize sclerotia of $S$. minor and reduce disease in peanut when active in the soil for three consecutive years (19). However, various environmental conditions and agrichemicals used in peanut production may affect the mycoparasitic activity of $C$. minitans $(8,15)$.

The environment influences the mycoparasitic activity of $C$. minitans. The optimum temperature for $C$. minitans spore germination, infection, and destruction of sclerotia of S. sclerotiorum is $20^{\circ} \mathrm{C}$ (23). Temperatures $<7^{\circ} \mathrm{C}$ are not favorable for

\section{Corresponding author: D. Partridge \\ E-mail: departri@vt.edu}

Accepted for publication 6 June 2006.

DOI: 10.1094/PD-90-1407

(C) 2006 The American Phytopathological Society the growth of $C$. minitans and reduce the rate of spore germination and infection (23). Optimum relative humidity for the mycoparasitism of $S$. sclerotiorum sclerotia is $>95 \%$ (23). In vitro studies found that $80 \%$ spore germination occurred after 7 days at temperatures ranging from 7 to $20^{\circ} \mathrm{C}$, and spore germination occurred at temperatures as low at $4^{\circ} \mathrm{C}$ and as high as $30^{\circ} \mathrm{C}(23)$.

In all, 23 fungicides, 12 insecticides, and 20 herbicides are recommended for use on peanut in North Carolina (13). Previous studies have examined the interaction of $C$. minitans with pesticides used in lettuce production, including the fungicides iprodione and thiram, which were found to reduce mycelial growth and spore germination, but not mycoparasitism of sclerotia of S. sclerotiorum (8). C. minitans growth and spore germination are also highly sensitive to benomyl and vinclozolin (50\% effective concentration $\left[\mathrm{EC}_{50} \mathrm{~s}\right]$ $<1 \mu \mathrm{g}$ a.i. $\mathrm{ml}^{-1}$ ) (15). Among the most widely used pesticides in peanut production are the fungicides azoxystrobin, pyraclostrobin, chlorothalonil, fluazinam, and tebuconazole and the herbicides diclosulam, flumioxazin, $S$-metolachlor, and pendimethalin (22). These pesticides potentially could interact with $C$. minitans in the field during the growing season.

For $C$. minitans to become widely accepted as a management tool, it must be successfully integrated with current pro- duction practices and persist and infect sclerotia of $S$. minor under field conditions. The objectives of this study were to determine the optimum temperature and moisture requirements for $C$. minitans infection of sclerotia of $S$. minor, and to evaluate the sensitivity of $C$. minitans to nine pesticides commonly used in peanut production to determine whether they could interfere with mycoparasitism on sclerotia of $S$. minor. Knowledge of these factors will allow us to better predict the potential for use of $C$. minitans in controlling Sclerotinia blight of peanut.

\section{MATERIALS AND METHODS}

Isolate information and production of sclerotia. An isolate of $C$. minitans (CON/M/91-08), obtained by plating out the commercial formulation Contans WG (Propyta Biologischer Pflanzenschutz GmbH, Malchow/Poel, Germany), was grown on potato dextrose agar (PDA) in an incubator at $18^{\circ} \mathrm{C}$ for 7 days. A spore suspension of $C$. minitans was made by flooding the culture dishes with sterilized water and gently scraping the colony surfaces to free conidia from the pycnidia. The spore suspension was adjusted to $1 \times 10^{6}$ conidia $\mathrm{ml}^{-1}$ with the aid of a hemacytometer.

An isolate of $S$. minor (no. 20, obtained from Dr. Barbara Shew, North Carolina State University; 10), originally isolated from a diseased peanut plant in Gatesville, $\mathrm{NC}$, was used in this study. Sclerotia were produced at $18^{\circ} \mathrm{C}$ on sterilized oat kernels infested with $S$. minor (1). After 5 weeks, oat kernels were dried for 2 weeks at room temperature (about $22^{\circ} \mathrm{C}$ ) and then stored in a refrigerator at $5^{\circ} \mathrm{C}$ until used in experiments.

Pesticides used. Commercial formulations of all pesticides were used in this study. Fungicides used and the maximum labeled rate for peanuts were azoxystrobin (Abound Flowable; Syngenta Crop Protection, Greensboro, NC) at $450 \mathrm{~g}$ a.i. ha ${ }^{-1}$, chlorothalonil (Bravo Weather Stik; Syngenta Crop Protection) at $1.26 \mathrm{~kg}$ a.i. ha ${ }^{-1}$, fluazinam (Omega 500F; Syngenta Crop Protection) at $875 \mathrm{~g}$ a.i. $\mathrm{ha}^{-1}$, pyraclostrobin (Headline; BASF Corp., Research Triangle Park, NC) at $275 \mathrm{~g}$ a.i. ha ${ }^{-1}$, and tebuconazole (Folicur 3.6 F; Bayer Crop Science, Research Triangle Park, NC) at $229 \mathrm{~g}$ a.i. $\mathrm{ha}^{-1}$. Herbicides and their corresponding maximum use rates were diclosulam (Strongarm; Dow AgroSciences LLC, Indianapolis, IN) at $27 \mathrm{~g}$ a.i. $\mathrm{ha}^{-1}$, 
flumioxazin (Valor; Valent U.S.A. Corp., Walnut Creek, CA) at $107 \mathrm{~g}$ a.i. $\mathrm{ha}^{-1}, \mathrm{~S}$ metolachlor (Dual Magnum; Syngenta Crop Protection) at $2.14 \mathrm{~kg}$ a.i. $\mathrm{ha}^{-1}$, and pendimethalin (Prowl H2O; BASF Corp.) at $1.07 \mathrm{~kg}$ a.i. $\mathrm{ha}^{-1}$. These herbicides are soil applied pre-plant incorporated (PPI) or pre-emergence (PRE) and, therefore, are most likely to interact with $C$. minitans in the soil early in the season.

Mycelial growth and conidia germination. Stock suspensions of each of the nine pesticides were prepared using sterile distilled water. The stock suspension of each pesticide then was adjusted to appropriate concentrations to achieve final concentrations of $0.01,0.1,1$, and $10 \mu \mathrm{g}$ a.i. $\mathrm{ml}^{-1}$ when added to molten PDA. PDA was autoclaved and cooled to $55^{\circ} \mathrm{C}$ before then being amended with each pesticide. The pesticide-amended medium $(15 \mathrm{ml})$ then was added to standard $9-\mathrm{cm}$ petri dishes. A $5-\mathrm{mm}$ plug taken from the margin of an actively growing 7-day-old culture of $C$. minitans was placed upside down in the center of each test dish. Dishes were incubated at $18^{\circ} \mathrm{C}$ and radial growth of $C$. minitans was measured in two axes every $48 \mathrm{~h}$ for 14 days. There were three replicate dishes for each of the pesticide treatments and experiments were conducted three times. Percentage of mycelial growth inhibition (PMGI) was calculated by the formula $\mathrm{PMGI}=100 \times\left(\left[\mathrm{D}_{\mathrm{PDA}}-\right.\right.$ $\left.\left.\mathrm{D}_{\mathrm{F}}\right] / \mathrm{D}_{\mathrm{PDA}}\right)$, where $\mathrm{D}_{\mathrm{PDA}}$ is the average colony diameter of $C$. minitans after 14 days of growth on PDA and $\mathrm{D}_{\mathrm{F}}$ is the colony diameter of $C$. minitans after 14 days of growth on PDA amended with each of the pesticides.

Germination of conidia of $C$. minitans was measured in the presence of the pesticides at $0.01,0.1,1$, and $10 \mu \mathrm{g}$ a.i. $\mathrm{ml}^{-1}$ by placing three drops of a conidial suspension $\left(5 \times 10^{5}\right.$ spores $\left./ \mathrm{ml}\right)$ on the surface of each dish of amended agar. The dishes were incubated at $18^{\circ} \mathrm{C}$ for $32 \mathrm{~h}$, at which time $85 \%$ lactic acid was added to each dish to stop conidial germination. Conidial germination was assessed by counting the number of germinated conidia out of 100 per spot on each dish using a compound microscope. A conidium was considered germinated when the germ tube length was equal to or greater than half the length of the conidium. There were three replicate dishes for each pesticide treatment and the experiment was repeated once. Percentage of conidial germination inhibition (PCGI) was calculated by the formula PCGI $=100$ $\times\left(\left[\mathrm{C}_{\mathrm{PDA}}-\mathrm{C}_{\mathrm{F}}\right] / \mathrm{C}_{\mathrm{PDA}}\right)$, where $\mathrm{C}_{\mathrm{PDA}}$ is the number of conidia that germinated on PDA after $32 \mathrm{~h}$ and $\mathrm{C}_{\mathrm{F}}$ is the number of conidia after $32 \mathrm{~h}$ that germinated on PDA amended with each pesticide.

Preparation of soil plates. Temperature, moisture, and pesticide effects on mycoparasitism of sclerotia of $S$. minor were studied using a modification of a soil plate technique described by Smith and
Phipps (20). A sample of a Rains fine sandy-loam soil was collected from a peanut field in Gatesville, NC with a history of Sclerotinia blight of peanut. Soil was air dried and sifted through a U.S. standard number 12 sieve (1.7-mm opening) to produce uniform-sized soil particles and to remove organic debris.

In the pesticide experiments, soil was autoclaved for $30 \mathrm{~min}\left(121^{\circ} \mathrm{C}\right.$ at $\left.103 \mathrm{kPa}\right)$ and allowed to cool; then, $30 \mathrm{~g}$ of soil was dispensed into a $9-\mathrm{cm}$ plastic petri dish and $10 \mathrm{ml}$ of sterile distilled water was added to each dish. Next, 20 sclerotia were placed on the soil surface and sprayed with a suspension of spores of $C$. minitans (approximately $1 \times 10^{6}$ spores $\mathrm{ml}^{-1}$ ) using an airbrush. The dishes were placed on a laboratory bench for $4 \mathrm{~h}$ to allow the spores to settle, after which an airbrush was used to apply the maximum labeled field rate of each pesticide across each dish. Maximum rates per hectare were converted to maximum rates per dish using surface area of the dish equal to $63.6 \mathrm{~cm}^{2}$. Dishes were incubated at $18^{\circ} \mathrm{C}$ for 14 days. After 14 days, sclerotia were removed from the soil plate to determine their viability and infection by $C$. minitans. The sclerotia were surface disinfested in $15 \% \mathrm{NaClO}$ for $30 \mathrm{~s}$, rinsed in sterilized distilled water, plated on PDA amended with tetracycline (25 mg liter ${ }^{-1}$ ), and incubated at $18^{\circ} \mathrm{C}$ for 14 days. Sclerotia were examined with a stereoscope and a compound microscope and those producing mycelium, whether or not they were infected by $C$. minitans, were considered viable. Both viable and nonviable sclerotia showing sporulation of $C$. minitans on the surface of the sclerotia were scored as infected. Each pesticide treatment plus a nontreated control was replicated three times and the experiment was repeated once.

In the temperature experiments, soil was amended with commercial cornmeal (5\% $\mathrm{wt} / \mathrm{wt}$ ) and thoroughly mixed, and $50 \mathrm{~g}$ of the amended soil was placed in 9-cm glass petri dishes. The amended soil was moistened with $20 \mathrm{ml}$ of distilled water, autoclaved for $30 \mathrm{~min}$ at $121^{\circ} \mathrm{C}(103 \mathrm{kPa})(20)$, and allowed to cool. Then, 20 sclerotia of $S$. minor were placed on the soil surface of each dish and sprayed uniformly with a suspension of spores of $C$. minitans (approximately $1 \times 10^{6}$ spores $\mathrm{ml}^{-1}$ ) using an airbrush. Dishes with soil and sclerotia then were placed in growth chambers at $14,18,22,28$, or $30^{\circ} \mathrm{C}$ for 14 days, after which time the sclerotia were removed from the soil dishes. The sclerotia were surface disinfested and plated on PDA as described earlier. The number of viable sclerotia and sclerotia infected by $C$. minitans were determined as described previously. For each temperature treatment, there were four replications plus a control with noninoculated sclerotia. The experiment was repeated once.
In the soil moisture experiments, field soil was dried for $24 \mathrm{~h}$ at $60^{\circ} \mathrm{C}$ to completely remove moisture. The soil was allowed to cool and $30 \mathrm{~g}$ of soil was dispensed into $9-\mathrm{cm}$ plastic petri dishes. A sample of the field soil was submitted to the Soil Physical Properties Laboratory, North Carolina State University, for a soil water retention analysis under pressures of $0,-0.1,-0.33,-0.5,-1,-8$, and $-15 \mathrm{kPa} \times$ $10^{2}$. Data from the soil water retention analysis were used to develop a soil release curve. Sterile distilled water was added by weight to each soil dish to obtain the moisture treatments of approximately $0,-0.10$, $-0.33,-1$, and $-15 \mathrm{kPa} \times 10^{2}$. Sclerotia were inoculated by dipping them into a $C$. minitans spore suspension (approximately $1 \times 10^{6}$ spores $\mathrm{ml}^{-1}$ ). The sclerotia were removed from the spore suspension and placed on sterilized filter paper to remove excess water. Then, 20 sclerotia were placed on the soil surface of each petri dish. Static Guard (Alberto-Culver Co., Melrose Park, IL) was applied to the top of each petri dish to prevent condensation on the lid and the dishes were sealed with Parafilm to maintain constant moisture. Preliminary experiments showed that Static Guard did not interfere with the mycoparasitic interaction but did inhibit the condensation of water on the lid. The weight of each dish was recorded to monitor soil moisture levels. Dishes then were placed in an incubator at $18^{\circ} \mathrm{C}$ for 14 days, after which time a final weight of the dishes was recorded and sclerotia removed. Sclerotia were surface disinfested and plated on PDA, and viable sclerotia and sclerotia infected by $C$. minitans were determined as described previously. Each moisture treatment was replicated four times and included a noninoculated control. The experiment was repeated once.

Data analyses. The experimental design was a randomized complete block for each experiment. Data from separate experiments were combined when statistical analysis indicated that variances were homogenous. Analysis of variance (ANOVA; version 8; SAS Institute Inc., Cary, NC) was used to separate the treatment effects on sclerotia viability and infection by $C$. minitans. Significant differences among treatments in each experiment were assessed using Fisher's protected least significant difference test at $P \leq 0.05$. Correlation analysis was used to compare the viability and infection of sclerotia. For calculation of $\mathrm{EC}_{50} \mathrm{~s}$, percentage of mycelial growth inhibition or conidia germination inhibition was plotted against the $\log _{10}$-transformed concentration of each pesticide to determine the linear relationship between the two parameters. $\mathrm{EC}_{50}$ values for each pesticide then were determined using the linear equation given by the general linear model (version 8; SAS Institute Inc.). 


\section{RESULTS}

Mycelial growth and conidial germination. Of the nine pesticides evaluated, all the fungicides and the herbicide flumioxazin reduced radial mycelial growth of C. minitans on PDA as shown by the slope of the regression of PMGI versus pesticide concentration $(P \leq 0.010$; Table 1$)$. Fluazinam was the most active compound tested, with calculated $\mathrm{EC}_{50}$ of $<0.01$ (Table 1). The calculated $\mathrm{EC}_{50}$ values for the remaining fungicides ranged from 0.15 to $0.90 \mu \mathrm{g}$ a.i. $\mathrm{ml}^{-1}$ except for azoxystrobin, which had an $\mathrm{EC}_{50}>10 \mu \mathrm{g}$ a.i. $\mathrm{ml}^{-1}$ (Table 1). At the higher concentrations, the QoI fungicides azoxystrobin and pyraclostrobin were less active than chlorothalonil, fluazinam, or tebuconazole (Table 1). Flumioxazin was the only herbicide with an $\mathrm{EC}_{50}$ for mycelial growth $<10 \mu \mathrm{g}$ a.i. $\mathrm{ml}^{-1}$ (Table 1).

Pyraclostrobin was the most active compound tested on $C$. minitans conidial germination at $0.01 \mu \mathrm{g}$ a.i. $\mathrm{ml}^{-1}$, reducing germination by $85 \%$ (Table 2). $\mathrm{EC}_{50} \mathrm{~s}$ for conidial germination for all fungicides except tebuconazole were $\leq 0.01 \mu \mathrm{g}$ a.i. $\mathrm{ml}^{-1}$ (Table 2). Flumioxazin was the only herbicide that reduced spore germination (Table 2). $\mathrm{EC}_{50} \mathrm{~s}$ for diclosulam, S-metolachlor, and pendimethalin could not be estimated reliably because they were greater than the highest concentration of a.i. used in this study (Table 2).

Mycoparasitic activity. All fungicides and the herbicides diclosulam, flumioxazin, and pendimethalin reduced infection of $S$. minor sclerotia by $C$. minitans compared with the nontreated control (Table 3). Viability of sclerotia was inversely related to the proportion infected by $C$. minitans $(r=-0.823, P<0.0001)$; as the percentage of infected sclerotia decreased, the percent viable sclerotia increased $(\mathrm{Ta}-$ ble 3 ). None of the nine pesticides tested completely prevented infection by $C$. minitans (Table 3). Azoxystrobin, chlorothalonil, fluazinam, pyraclostrobin, and flumi- oxazin treatments had the greatest effect on infection of the sclerotia by $C$. minitans (Table 3).

Infection of sclerotia of $S$. minor by $C$. minitans increased as soil moisture level decreased from 0 to $-1 \mathrm{kPa} \times 10^{2}$ (Fig. 1). The largest percentage of sclerotia were infected between -1 and $-0.33 \mathrm{kPa} \times 10^{2}$. Infection declined as soil moisture was reduced to $-15 \mathrm{kPa} \times 10^{2}$ (Fig. 1). Viability of inoculated $S$. minor sclerotia was inversely related to the proportion of sclerotia infected by $C$. minitans $(r=-0.572, P$ $<0.0001)$. As the percentage of sclerotia infected by $C$. minitans increased from 0 to $-1 \mathrm{kPa} \times 10^{2}$ after 14 days, viability of sclerotia decreased from 98 to $90 \%$ (Fig. 1). Viable sclerotia then increased to $98 \%$ at $-15 \mathrm{kPa} \times 10^{2}$ while the number of infected sclerotia was reduced (Fig. 1).

Mycoparasitic activity of $C$. minitans remained high (98\% sclerotia infected) at temperatures ranging from 14 to $22^{\circ} \mathrm{C}$, but decreased dramatically at temperatures

Table 1. Colony diameter, regression parameters, and $50 \%$ effective concentration $\left(\mathrm{EC}_{50}\right)$ values $\left(\mu \mathrm{g} \mathrm{a.i.} \mathrm{ml}^{-1}\right)$ of Coniothyrium minitans isolate $\mathrm{CON} / \mathrm{M} / 91$ 08 on potato dextrose agar (PDA) amended with fungicides or herbicides commonly used in peanut production ${ }^{\mathrm{x}}$

\begin{tabular}{|c|c|c|c|c|c|c|c|c|c|}
\hline \multirow[b]{2}{*}{ Pesticide } & \multicolumn{5}{|c|}{ Colony diameter $(\mathrm{mm})$ for pesticide concentration $\left(\mu \mathrm{g}\right.$ a.i. $\left.\mathrm{ml}^{-1}\right)$} & \multirow[b]{2}{*}{ Slope ${ }^{y}$} & \multirow[b]{2}{*}{$R^{2}$} & \multirow[b]{2}{*}{$P$ slope } & \multirow[b]{2}{*}{ MG EC $\mathrm{E}_{50} \mathrm{z}$} \\
\hline & $\mathbf{0}$ & 0.01 & 0.1 & 1 & 10 & & & & \\
\hline \multicolumn{10}{|l|}{ Fungicide } \\
\hline Azoxystrobin & 76.8 & 55.6 & 50.8 & 47.1 & 44.4 & 5.03 & 0.179 & 0.0101 & $>10(-)$ \\
\hline Chlorothalonil & 76.8 & 60.1 & 33.8 & 19.3 & 16.4 & 19.54 & 0.775 & $<0.0001$ & 0.15 \\
\hline Fluazinam & 76.8 & 38.5 & 21.1 & 16.4 & 14.4 & 10.35 & 0.679 & $<0.0001$ & $<0.01$ \\
\hline Pyraclostrobin & 76.8 & 51.0 & 47.6 & 34.5 & 29.9 & 10.24 & 0.592 & $<0.0001$ & 0.90 \\
\hline Tebuconazole & 76.8 & 69.8 & 48.7 & 25.6 & 10.8 & 26.83 & 0.934 & $<0.0001$ & 0.38 \\
\hline \multicolumn{10}{|l|}{ Herbicide } \\
\hline Diclosulam & 76.8 & 77.4 & 71.4 & 78.9 & 78.1 & -0.13 & 0.019 & 0.4329 & $>10(-)$ \\
\hline Flumioxazin & 76.8 & 76.9 & 66.8 & 35.5 & 33.1 & 21.88 & 0.719 & $<0.0001$ & 2.93 \\
\hline$S$-Metolachlor & 76.8 & 79.8 & 78.2 & 74.1 & 77.0 & 1.65 & 0.043 & 0.2263 & $>10(-)$ \\
\hline Pendimethalin & 76.8 & 78.9 & 74.5 & 77.5 & 76.7 & 0.50 & 0.005 & 0.6879 & $>10(-)$ \\
\hline
\end{tabular}

${ }^{x}$ Growth (mm) after 14 days of incubation. Data represent the mean of three repetitions with three replicates each.

y Slope of inhibition determined from the regression of percent mycelial growth inhibition (PMGI) versus $\log _{10}$-transformed concentration of each pesticide, where PMGI $=100 \times\left(\left[\mathrm{D}_{\mathrm{PDA}}-\mathrm{D}_{\mathrm{F}}\right] / \mathrm{D}_{\mathrm{PDA}}\right)$, where $\mathrm{D}_{\mathrm{PDA}}$ is the average colony diameter of $C$. minitans after 14 days of growth on PDA and $\mathrm{D}_{\mathrm{F}}$ is the colony diameter of $C$. minitans after 14 days of growth on PDA amended with each of the pesticides.

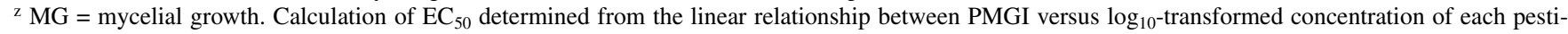
cide. The $\mathrm{EC}_{50} \mathrm{~s}$ for each pesticide then were determined using the linear equation given by the general linear model; $(-)=$ no effect within confines of experiment.

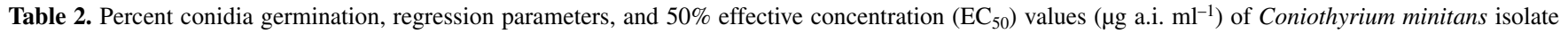
$\mathrm{CON} / \mathrm{M} / 91-08$ after $32 \mathrm{~h}$ at $18^{\circ} \mathrm{C}$ on potato dextrose agar (PDA) amended with pesticides commonly used in peanut production ${ }^{\mathrm{x}}$

\begin{tabular}{|c|c|c|c|c|c|c|c|c|c|}
\hline \multirow[b]{2}{*}{ Pesticide } & \multicolumn{5}{|c|}{ Germinated spores $(\%)$ for pesticide concentration $\left(\mu \mathrm{g}\right.$ a.i. $\mathrm{ml}^{-1}$ ) } & \multirow[b]{2}{*}{ Slope ${ }^{y}$} & \multirow[b]{2}{*}{$R^{2}$} & \multirow[b]{2}{*}{$P$ slope } & \multirow[b]{2}{*}{$\mathrm{CG} \mathrm{EC}_{50}$} \\
\hline & $\mathbf{0}$ & 0.01 & 0.1 & 1 & 10 & & & & \\
\hline \multicolumn{10}{|l|}{ Fungicide } \\
\hline Azoxystrobin & 69.7 & 40.3 & 16.5 & 6.3 & 3.8 & 12.05 & 0.781 & $<0.0001$ & $<0.01$ \\
\hline Chlorothalonil & 69.7 & 33.8 & 5.7 & 1.8 & 0.7 & 10.12 & 0.644 & $<0.0001$ & $<0.01$ \\
\hline Fluazinam & 69.7 & 49.0 & 8.5 & 2.0 & 0.3 & 15.11 & 0.640 & $<0.0001$ & 0.01 \\
\hline Pyraclostrobin & 69.7 & 8.3 & 5.3 & 2.0 & 0.7 & 2.68 & 0.667 & $<0.0001$ & $<0.01$ \\
\hline Tebuconazole & 69.7 & 50.3 & 40.0 & 13.7 & 6.8 & 16.40 & 0.900 & $<0.0001$ & 0.25 \\
\hline \multicolumn{10}{|l|}{ Herbicide } \\
\hline Diclosulam & 69.7 & 48.0 & 47.3 & 47.8 & 48.8 & -0.04 & 0.011 & 0.6336 & $(-)$ \\
\hline Flumioxazin & 69.7 & 46.3 & 23.0 & 12.8 & 10.3 & 11.58 & 0.713 & $<0.0001$ & 0.03 \\
\hline$S$-Metolachlor & 69.7 & 45.2 & 46.2 & 46.3 & 40.3 & 1.34 & 0.105 & 0.1233 & $>10(-)$ \\
\hline Pendimethalin & 69.7 & 48.2 & 52.5 & 51.2 & 50.2 & -0.04 & 0.013 & 0.5999 & $(-)$ \\
\hline
\end{tabular}

${ }^{x}$ Percentage of germinated spores out of 100. Data represents the mean of two repetitions with three replicates each.

y Slope of inhibition determined from the regression of percent inhibition of conidia germination versus $\log _{10}$ transformed concentration of each pesticide. Where percentage of conidia germination inhibition (PCGI) was calculated by the formula PCGI $\left.=100 \times\left(\left[\mathrm{C}_{\mathrm{PDA}}-\mathrm{C}_{\mathrm{F}}\right) / \mathrm{C}_{\mathrm{PDA}}\right]\right)$, where $\mathrm{C}_{\mathrm{PDA}}$ is the number of conidia that germinated on PDA after $32 \mathrm{~h}$ and $\mathrm{C}_{\mathrm{F}}$ is the number of conidia after $32 \mathrm{~h}$ that germinated on PDA amended with each pesticide.

${ }^{\mathrm{z}} \mathrm{CG}=$ conidia germination. Calculation of $\mathrm{EC}_{50}$ determined from the linear relationship between PCGI versus $\log _{10}$-transformed concentration of each pesticide. The $\mathrm{EC}_{50} \mathrm{~s}$ for each pesticide were then determined using the linear equation given by the general linear model; $(-)=$ no effect within confines of experiment. 
$\geq 28^{\circ} \mathrm{C}$, where only $9 \%$ sclerotia were infected. (Fig. 2). Viability of S. minor sclerotia was inversely related to proportion of those sclerotia infected by $C$. minitans $(r=$ $-0.963, P<0.0001)$. At all temperatures, the noninoculated sclerotia were $100 \%$ viable (Fig. 2).

\section{DISCUSSION}

In this study, mycelial growth, spore germination, and mycoparasitic activity of C. minitans were inhibited by most fungicides and one herbicide commonly used in peanut production. $C$. minitans was most sensitive to the fungicides azoxystrobin, fluazinam, chlorothalonil, pyraclostrobin, and tebuconazole and the herbicide flumi- oxazin. Each of these fungicides have broad-spectrum activity against basidiomycota, ascomycota, and deuteromycota (16). Azoxystrobin, chlorothalonil, and pyraclostrobin have good activity on web blotch of peanut caused by Phoma arachidicola (9). The genera Phoma and Coniothyrium are anamorphs of fungi in the family Leptosphaeriaceae (2); therefore, it is not unexpected that $C$. minitans is sensitive to the same fungicides used to control $P$. arachidicola and leaf spot (Cercospora arachidicola).

The herbicide flumioxazin, used to control a number of problematic weeds in peanut, including Florida beggarweed (Desmodium tortuosum (Sw.) DC.), com-

Table 3. Mycoparasitic activity of Coniothyrium minitans on sclerotia of Sclerotinia minor in soil plates in the presence of the maximum recommended field concentration of pesticides commonly used in peanut production

\begin{tabular}{|c|c|c|c|}
\hline \multirow[b]{2}{*}{ Pesticide $^{w}$} & \multirow[b]{2}{*}{ Rate $\left(g \text { a.i. } \text { ha }^{-1}\right)^{x}$} & \multicolumn{2}{|c|}{ S. minor sclerotia ${ }^{v}$} \\
\hline & & Infected $^{y}$ & Viable $^{z}$ \\
\hline Nontreated control & $\ldots$ & $50.8 \mathrm{a}$ & $60.8 \mathrm{c}$ \\
\hline \multicolumn{4}{|l|}{ Fungicides } \\
\hline Azoxystrobin & 450 & $12.5 \mathrm{~d}$ & $83.3 \mathrm{ab}$ \\
\hline Chlorothalonil & 1,260 & $14.2 \mathrm{~d}$ & $90.0 \mathrm{a}$ \\
\hline Fluazinam & 875 & $21.7 \mathrm{~cd}$ & $80.8 \mathrm{ab}$ \\
\hline Pyraclostrobin & 275 & $10.8 \mathrm{~d}$ & $90.0 \mathrm{a}$ \\
\hline Tebuconazole & 229 & $35.8 \mathrm{~b}$ & $73.3 \mathrm{cb}$ \\
\hline \multicolumn{4}{|l|}{ Herbicides } \\
\hline Diclosulam & 27 & $31.7 \mathrm{bc}$ & $70.8 \mathrm{cb}$ \\
\hline Flumioxazin & 107 & $18.3 \mathrm{~d}$ & $80.0 \mathrm{ab}$ \\
\hline$S$-Metolachlor & 2,140 & $38.3 \mathrm{ab}$ & $64.2 \mathrm{c}$ \\
\hline Pendimethalin & 1,070 & $37.5 \mathrm{~b}$ & $71.7 \mathrm{cb}$ \\
\hline$F(\operatorname{Pr}>F)$ & $\ldots$ & $9.3(<0.0001)$ & $4.0(0.0008)$ \\
\hline LSD & $\ldots$ & 12.6 & 14.3 \\
\hline
\end{tabular}

${ }^{v}$ Values followed by the same letter in each column are not significantly different at a $P \leq 0.05$ according the Fisher's protected least significant difference (LSD).

w Pesticides used were from commercial formulations.

${ }^{\mathrm{x}}$ Maximum application rate.

${ }^{y}$ Infected by $C$. minitans. Percentage of both viable and nonviable sclerotia infected by $C$. minitans after 14 days. Data represents average results from two trials with 20 sclerotia each.

${ }^{\mathrm{z}}$ Percentage of sclerotia germinating after 14 days whether or not they were infected by $C$. minitans. Data represent average results from two trials with 20 sclerotia each.

\section{目Infected $\square$ Viable inoculated $\square$ Viable noninoculated}

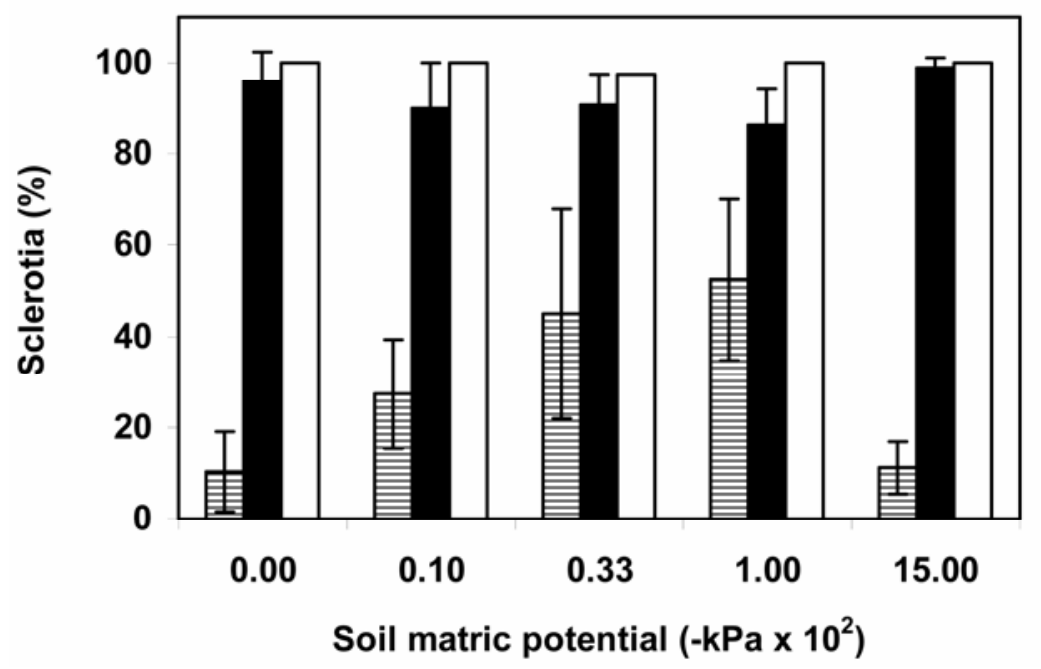

Fig. 1. Effects of soil moisture on infection of Sclerotinia minor sclerotia by Coniothyrium minitans. Percentage of sclerotia that were viable or infected by $C$. minitans after 14 days of incubation at $18^{\circ} \mathrm{C}$ with soil moistures ranging from 0 to $-15-\mathrm{kPa} \times 10^{2}$.

mon ragweed (Ambrosia artemisiifolia L.), and eclipta (Eclipta prostrata L.) (3), was found to have activity similar to that of many of the fungicides tested in reducing fungal growth and mycoparasitic activity of Coniothyrium minitans. The herbicide lactofen, an inhibitor of protophyrinogen oxidase, has been found to reduce early leaf spot on peanut (caused by Cercospora arachidicola) by reducing spore germination and decreasing sporulation in lesions (4). Because lactofen has fungicidal activity, it was not unexpected that flumioxazin, a herbicide that also inhibits protophyrinogen oxidase, showed fungicidal activity in reducing Coniothyrium minitans growth, spore germination, and mycoparasitic activity.

In our study, mycelial growth and spore germination of $C$. minitans was highly sensitive to chlorothalonil, fluazinam, pyraclostrobin, tebuconazole, and flumioxazin. Spore germination also was highly sensitive to azoxystrobin. Mycelial growth and spore germination were less sensitive to the herbicides diclosulam, $S$ metolachlor, and pendimethalin. Budge and Whipps (7) found that C. minitans growth and spore germination were sensitive in vitro to pesticides, including the fungicides iprodione, thiram, mancozeb, metalaxyl, tolclofos-methyl, and zineb, along with a number of insecticides and the herbicide combination chloropopham + cetrimide used in lettuce production. Li et al. (15) also found that $C$. minitans was highly sensitive in vitro to benomyl and vinclozolin $\left(\mathrm{EC}_{50} \mathrm{~s}<1 \mu \mathrm{g}\right.$ a.i. $\left.\mathrm{ml}^{-1}\right)$.

Although most pesticides tested in soil plates reduced the number of sclerotia infected by $C$. minitans, sufficient inocula survived to infect at least $10 \%$ of the sclerotia of $S$. minor. This activity may be a result of escapes because of incomplete coverage of the sclerotia by the pesticides. In the field, these pesticides are applied to the peanut plant or the soil surface, and residuals of the active ingredient that eventually enter the soil likely would be much lower than those used in our test. Nevertheless, the $\mathrm{EC}_{50} \mathrm{~s}$ for inhibition of spore germination and mycelial growth were less than $1 \mu \mathrm{g}$ a.i./ml for all the fungicides except azoxystrobin, indicating that $C$. minitans is very sensitive to these pesticides. C. minitans was found to successfully parasitize sclerotia of $S$. minor in field trials where traditional peanut production practices were implemented, including the application of fluazinam and other fungicides for disease control (19). However, $C$. minitans is very sensitive to these pesticides and care should be taken in the timing of the application of the biological control agent relative to pesticide application, because growth, spore germination, and mycoparasitic activity of $C$. minitans potentially could be reduced in their presence. C. minitans should not be applied with pesticides or during times when there 
is a high risk of direct contact with azoxystrobin, chlorothalonil, fluazinam, pyraclostrobin, tebuconazole, and flumioxazin.

Soil temperature and moisture influenced the ability of $C$. minitans to infect sclerotia of $S$. minor. Optimum infection of sclerotia by $C$. minitans occurred with soil moisture ranging from -0.33 to $-1 \mathrm{kPa} \times$ $10^{-2}$ and temperatures ranging from 14 to $22^{\circ} \mathrm{C}$. These temperatures and moisture conditions are typical throughout most of the year in peanut fields in North Carolina, where the 30-year average daily maximum temperatures from 1971 to 2000 was $22.0^{\circ} \mathrm{C}$ and the average minimum was $9.7^{\circ} \mathrm{C}$ (30-year weather data obtain from the State Climate Office of North Carolina from weather stations located in Lewiston and Edenton, NC).

Both extremely wet and dry soil moisture reduced the ability of $C$. minitans to infect sclerotia of $S$. minor. S. minor sclerotia viability decreased from 98 to $90 \%$ and $C$. minitans infection increased from 10 to $45 \%$ with increasing soil moisture. Other studies also have shown the importance of moisture on the activity of $C$. minitans $(7,23,24)$. Sclerotia of $S$. sclerotiorum in celery and lettuce crops grown in a glasshouse were infected by $C$. minitans at all times of the year; however, the sclerotia failed to degrade during the summer months when the soil was dry (7). In culture, mycelial extension of $C$. minitans decreased as PDA was osmotically adjusted from -0.7 to $-7.0 \mathrm{MPa}$ (27), and relative humidity $\geq 90 \%$ is required for $C$. minitans spore germination, with $\geq 95 \%$ required for maximum germination and infection of S. sclerotiorum (23).

C. minitans was active at temperatures ranging from 14 to $22^{\circ} \mathrm{C}$, infecting more than $98 \%$ of the sclerotia and significantly reducing their viability. These results are consistent with the findings of Budge et al. (8) and Trutmann et al. (23), who found that infection of sclerotia of $S$. sclerotiorum by $C$. minitans occurred between 4 and $25^{\circ} \mathrm{C}$, with the optimum occurring at $20^{\circ} \mathrm{C}$. We mainly were interested in the effect of high temperatures on the mycoparasitic activity of $C$. minitans on sclerotia of $S$. minor. Previous studies have shown that spores of $C$. minitans are able to survive in cold storage at $5^{\circ} \mathrm{C}$ for up 64 weeks (18), and spore germination occurs at temperatures at low as $4^{\circ} \mathrm{C}(23)$. Also, extremely low temperatures in North Carolina usually are short lived and probably would not be detrimental to $C$. minitans spore survival and germination (minimum average soil temperatures ranged from 5.9 to $26.5^{\circ} \mathrm{C} ; 21$ ).

Spores of $C$. minitans can germinate at $30^{\circ} \mathrm{C}$ (23), but temperatures exceeding $26^{\circ} \mathrm{C}$ have been shown to inhibit infection of $S$. sclerotiorum by $C$. minitans (12). In our study, infection of sclerotia of $S$. minor by our isolate of $C$. minitans was significantly reduced at temperatures $\geq 28^{\circ} \mathrm{C}$, but some activity (9\% of sclerotia infected) was still detected at $30^{\circ} \mathrm{C}$ after 14 days. During the summer months in northeastern North Carolina, soil temperature can reach $32^{\circ} \mathrm{C}(21)$. Both air and soil temperatures consistently exceed $28^{\circ} \mathrm{C}$ during the months of June, July, and August (21). Therefore, C. minitans should persist and infect sclerotia of $S$. minor in the soil throughout most of the year in North Carolina.

After peanut harvest in the fall or early spring may be the best time to apply $C$. minitans to the soil for the biological control of $S$. minor. After harvest, in early to mid-October, temperatures remain favor-

\section{目Infected $\square$ Viable inoculated $\square$ Viable non-inoculated}

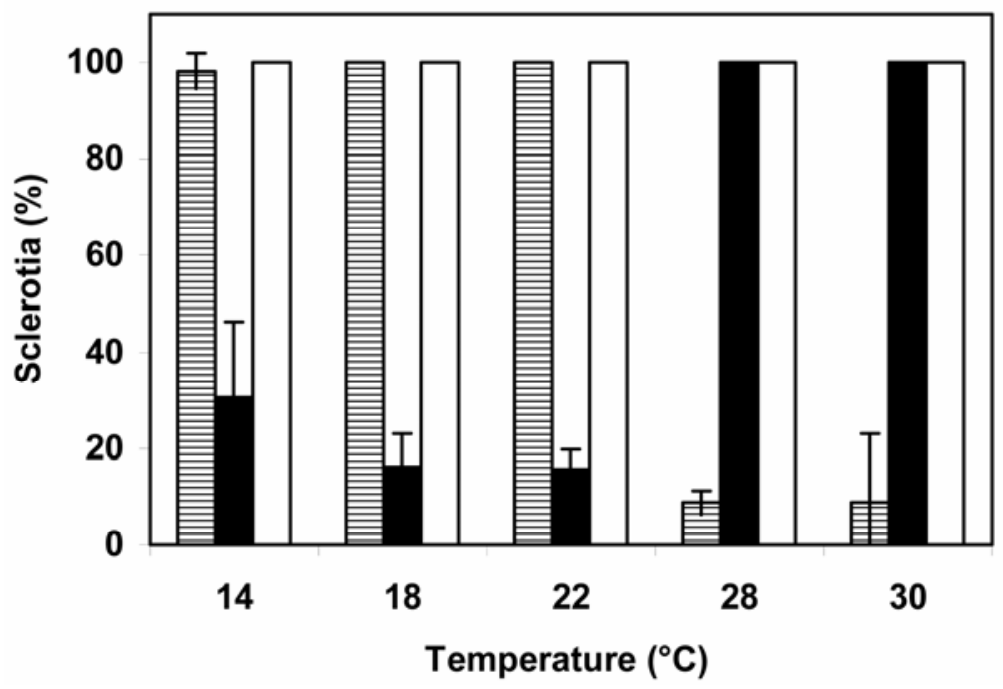

Fig. 2. Effect of temperature on mycoparasitism of Sclerotinia minor sclerotia by Coniothyrium minitans. Percentage of sclerotia that were viable or infected by $C$. minitans after 14 days of incubation at temperatures ranging from 14 to $30^{\circ} \mathrm{C}$.

able for infection for at least 6 weeks. However, October tends to be a dry month in North Carolina; therefore early spring (March) applications may be more effective. Because $C$. minitans survives cold temperatures, application during the winter also is likely to be effective as long as there is adequate soil moisture. In a longterm study, we found that multiple applications of $C$. minitans made in November, December, and February were effective in reducing numbers of sclerotia of $S$. minor and Sclerotinia blight of peanut (19). Therefore, if $C$. minitans is applied in the fall and has a chance to become established in the soil, by spring and summer months, when herbicides and fungicides are used in peanut production, the effects on $C$. minitans mycoparasitic activity will be minimized.

\section{ACKNOWLEDGMENTS}

This research was supported by funds provided by the North Carolina Peanut Growers Association, National Peanut Board, and the IR-4 Program. We thank Y. L. Lu and O. Anas for their help and guidance and G. Lou for technical support.

\section{LITERATURE CITED}

1. Adams, P. B. 1975. Factors affecting survival of Sclerotinia sclerotiorum in soil. Plant Dis. Rep. 59:599-603.

2. Alexopoulos, C. J., Mims, C. W., and Blackwell, M. 1996. Introductory Mycology, 4th ed. John Wiley \& Sons, Inc., New York.

3. Askew, S. D., Wilcut, J. W., and Crammer, J. R. 1999. Weed management in peanut (Arachis hypogaea) with flumioxazin preemergence. Weed Technol. 13:594-598.

4. Baysinger, J. A., Melouk, H. A., and Murray, D. S. 1999. Effects of postemergence herbicides on Cercospora arachidicola Hori and early leaf spot of peanut. Peanut Sci. 26:4-8.

5. Beute, M. K., Porter, D. M., and Hadley, B. A. 1975. Sclerotinia blight of peanut in North Carolina and Virginia and its chemical control. Plant Dis. Rep. 59:697-701.

6. Budge, S. P., McQuilken, M. P., Fenlon, J. S., and Whipps, J. M. 1995. Use of Coniothyrium minitans and Gliocladium virens for biological control of Sclerotinia sclerotiorum in glasshouse lettuce. Biol. Control 5:513-522.

7. Budge, S. P., and Whipps, J. M. 1991. Glasshouse trials of Coniothyrium minitans and Trichoderma species for the biological control of Sclerotinia sclerotiorum in celery and lettuce. Plant Pathol. 40:59-66.

8. Budge, S. P., and Whipps, J. M. 2001. Potential for integrated control of Sclerotinia sclerotiorum in glasshouse lettuce using Coniothyrium minitans and reduced fungicide application. Phytopathology 91:221-227.

9. Cole, D. L., and Liddell, C. 1997. Web blotch Pages 39-40 in: Compendium of Peanut Diseases, 2nd ed. N. Kokalis-Burelle, D. M. Porter, R. Rodriguez-Kabana, D. H. Smith, and P. Subrahmanyam, eds. American Phytopathological Society Press, St. Paul, MN.

10. Hollowell, J. E., Shew, B. B., and Isleib, T. G. 2003. Evaluating isolate aggressiveness and host resistance from peanut leaflet inoculations with Sclerotinia minor. Plant Dis. 87:402-406.

11. Huang, H. C. 1980. Control of Sclerotinia wilt of sunflower by hyperparasites. Can. J. Plant Pathol. 2:26-32.

12. Jones, E. E., Clarkson, J. P., Mead, A., and Whipps, J. M. 2004. Effect of inoculum type and timing of application of Coniothyrium minitans on Sclerotinia sclerotiorum: influence on apothecial production. Plant Pathol. 53:621-628. 
13. Jordan, D. L., Ferguson-Spears, J. M., Brandenburg, R. L., Brown, A. B., Shew, B. B., Roberson, G. T., and Bullen, S. G. 2005. 2005 Peanut Information. AG-331. North Carolina Cooperative Extension Service, North Carolina State University, Raleigh.

14. Kohn, L. M. 1979. A monographic revision of the genus Sclerotinia. Mycotaxon 9:365-444.

15. Li, G. Q., Huang, H. C., and Acharva, S. N. 2002. Sensitivity of Ulcladium atrum, Coniothyrium minitans, and Sclerotinia sclerotiorum to benomyl and vinclozolin. Can. J. Bot. 80:892-898.

16. Lyr, H. 1995. Modern Selective Fungicides. Gustav Fisher Verlag, New York.

17. McLaren, D. L., Kozub, G. C., and Rimmer, S. R. 1994. Biological control of Sclerotinia wilt of sunflower with Talaromyces flavus and Coniothyrium minitans. Plant Dis. 78:231-235.

18. McQuilken, M. P., Michell, S. J., Budge, S. P., Whipps, J. M., Fenlon, J. S., and Archer, S. A. 1995. Effect of Coniothyrium minitans on sclerotial survival and apothecial production of
Sclerotinia sclerotiorum in field-grown oilseed rape. Plant Pathol. 44:883-896.

19. Partridge, D. E., Sutton, T. B., Jordan, D. L., Curtis, V. L., and Bailey, J. E. 2006. Management of Sclerotinia blight of peanut with the biological control agent Coniothyrium minitans. Plant Dis. 90:957-963.

20. Smith, F. D., and Phipps, P. M. 1991. Agar plate, soil plate, and field evaluation of fluazinam and other fungicides for control of Sclerotinia minor on peanut. Plant Dis. 75:11381143.

21. State Climate Office of North Carolina. NC CRONOS Database, Raleigh, NC.

22. Toth, S. J., Jr. 1998. Peanut pesticide use survey in North Carolina. Data report to the USDA NAPIAP. N. C. Coop. Ext. Serv. Raleigh, NC.

23. Trutmann, P., Keane, P. J., and Merriman, P. R. 1980. Reduction of sclerotial inoculum of Sclerotinia sclerotiorum with Coniothyrium minitans. Soil Biol. Biochem. 12:461-465.

24. Trutmann, P., Keane, P. J., and Merriman, P R.
1985. Influence of environmental factors and sclerotial origin on parasitism of Sclerotinia sclerotiorum by Coniothyrium minitans Pages 221-223 in: Ecology and Management of Soilborne Plant Pathogens. C. A. Parker, A. D. Rovira, K. J. Moore, and P. T. W. Wong, eds. The American Phytopathological Society, St. Paul, MN.

25. Wadsworth, D. F. 1979. Sclerotinia blight of peanut in Oklahoma and occurrence of the sexual stage of the pathogen. Peanut Sci. 6:77-79.

26. Whipps, J. M., Budge, S. P., and Mitchell, S. J. 1993. Observations on sclerotial mycoparasites of Sclerotinia sclerotiorum. Mycol. Res. 97:697-700.

27. Whipps, J. M., and Magan, N. 1987. Effects of nutrient status and water potential of media on fungal growth and antagonist-pathogen interactions. EPPO Bull. 17:581-591.

28. Whipps, J. M., Mcquilken, M. P., and Budge, S. P. 1993. Use of fungal antagonists for biocontrol of damping-off and Sclerotinia diseases. Pestic. Sci. 37:309-313. 